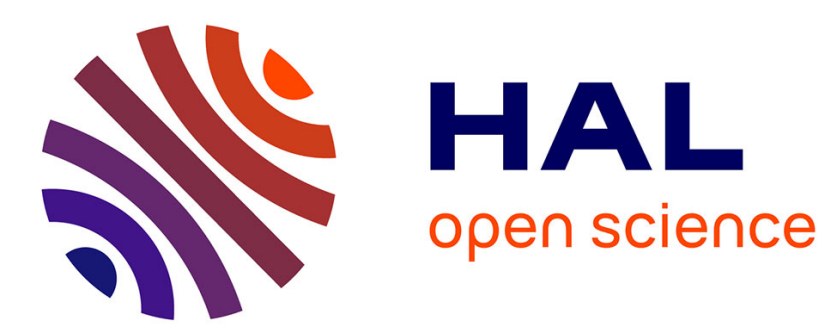

\title{
Observing innovation impacts on supply chain: the case of the Swatch
}

Brunelle Marche, Vincent Boly, J. Roland Ortt

\section{To cite this version:}

Brunelle Marche, Vincent Boly, J. Roland Ortt. Observing innovation impacts on supply chain: the case of the Swatch. International Conference on Engineering, Technology \& Innovation, Jun 2016, Trondheim, Norway. hal-01891266

\section{HAL Id: hal-01891266 https://hal.science/hal-01891266}

Submitted on 15 Oct 2018

HAL is a multi-disciplinary open access archive for the deposit and dissemination of scientific research documents, whether they are published or not. The documents may come from teaching and research institutions in France or abroad, or from public or private research centers.
L'archive ouverte pluridisciplinaire HAL, est destinée au dépôt et à la diffusion de documents scientifiques de niveau recherche, publiés ou non, émanant des établissements d'enseignement et de recherche français ou étrangers, des laboratoires publics ou privés. 


\section{Observing innovation impacts on supply chain: the case of the Swatch}

\author{
Brunelle MARCHE, Vincent BOLY \\ ERPI - Equipe de recherché sur les Processus Innovatifs \\ Université de Lorraine \\ Nancy, France \\ \{brunelle.marche, vincent.boly\}@univ-lorraine.fr
}

\author{
J. Roland ORTT \\ Faculty of Technology \\ Policy and Management \\ Delft, the Netherlands \\ J.R.Ortt@tudelft.nl
}

\begin{abstract}
Innovation impacts the company and its environment. This paper presents a case study for visualizing the innovation impacts on the company's supply chain. Using a historic case study, we explore how innovations can affect the organization of a supply chain. The company and stakeholders belonging to the supply chain were thoroughly studied. Using data from the literature, the research objective is a better understanding of the influences of innovation on the organization of the supply chain. A methodology is developed to model the supply chain before and after the emergence of the innovation. The evolution inside and outside of the company following the strategic choices, are observed. In this way, the impact of the innovation on the supply chain can be detailed. The results of this study show scenarios to design a new supply chain after the emergence of an innovation. In the future, a methodology will be developed to help managers to anticipate impacts caused by innovation.
\end{abstract}

Keywords - Innovation, Supply chain, Empirical case study, Data analysis

\section{INTRODUCTION}

A radical innovation brings novelty to the company but also to its supply chain [1]. The company's activities and its environment undergo changes following the launch of the new product on the market. To ensure the success of its new product, a company implements different strategies that impact its inner functioning but also other companies belonging to its supply chain. The company's strategic decisions are related to the changes in its environment. A better understanding of the strategies is needed to understand their impact on the supply chain. Through a systemic representation, this research attempts to explain the relationship between the development of innovations and the changes induced inside and outside the company.

To understand these phenomena, our study focuses on a historical innovation based on an explorative research: the case of the Swatch. The history of this innovation has been thoroughly studied to model its impact on the company and its supply chain. While the Swiss watch industry is in crisis in the 1980s, the Japanese low-end watches appear on the market. Innovations in Swiss watch companies are hampered by strict organization cartel. The Swatch, supported by emblematic stakeholders, emerges in a company specializing exclusively in the movement-blanks manufacture.
Its development involves a radical change of activity for the company and strongly impacts the cartel structuring. In the Swatch case, project manager have a certain vision of the supply chain required to develop their innovation as shown in this paper.

Indeed, the cartel structuring imposes companies to be specialized in one field of expertise. The Swatch development requires the company to acquire new skills, develop new activities to ensure the success of the product on the market. Then, the company's supply chain undergoes changes that will result from strategic choices applied to foster the product development.

The benefit of this inductive research is to study different perspectives to lead futures research and to better understand phenomena. In this way, different research perspectives will ermerge.

This article is structured as follows. Initially, existing theories will be related to this work. Then, the methodology is presented and the results are detailed: the environmental impacts of innovation are explained. Finally, the analysis and the conclusion of this research work are proposed.

\section{RELATION TO EXISTING THEORIES AND WORK}

\section{A. Characterization of the studied system}

This study integrates two dimensions: the company's value chain and its supply chain.

The value chain describes internal activities enabling the company to bring a product from conception to commercialization. Nine activities are clearly defined and divided into two categories. Support activities include the firm infrastructure, human resource management, technological development and procurement while core activities include inbound and outbound logistics, operations, marketing and sales, and services [2].

The supply chain is a complex notion, several definitions are proposed in the literature. Christopher characterizes a supply chain as a network of companies involved in the processes, upstream and downstream, that create value in the form of 
services or product provided for the final customer [3]. In France, the concept of supply chain is characterized by the filière notion. The definition proposed recently by Assogba and Klebaner includes several dimensions such as material, stakeholders, knowledge. In their approach, a filière is considered as a set of firms belonging to different competitive spheres, interconnected by vertical, coordinated and cooperative relationships, contributing to the achievement of the same good, sharing a common representation of issues affecting demand, employment, financing and supply relationship [4]. The set of firms are bound by physical, financial and informational flows [5].

In this article, this latter definition will be considered to characterize the concept of supply chain.

\section{B. Adopting a systemic approach}

A system is the basic concept of systemic analysis, which is an approach to better understand and better describe the organized complexity, a methodology to gather and organize knowledge for more effective action [6].To represent accurately the supply chain, a system representation seems appropriate. The systemic paradigm represents a company as a complex system. This complex system is defined by three aspects: its structure, its activity and its evolution. As an innovative company may be considered like a global, dynamic model, open to its environment, this representation is suitable [7], [8].

According to Le Moigne [7], [8], several perspectives are provided by this model:

- Global: different views are realized to see links between stakeholders in the product life cycle.

- Dynamic: the interactions required to the activity of the modeled organization are emphasized.

- Evolving: the changes within the organization or its environment are considered.

- Open: information and resources exchanges in the environment in which the company operates take place.

\section{Studied perspectives}

Innovation impacts company activities since it requires new skills [9]. Stakeholders belonging to the ecosystem are influenced by the consequences of these impacts [10]. Different perspectives may be considered to clearly define the concept of ecosystem.

\section{1) A "production optimization" perspective}

This perspective highlights the importance of production optimization following a process innovation.

A process innovation is the development of new or improved production methods: this includes changes on hardware, human resources or on working methods. Integration of new production methods involves modifications of the equipment or the production organization. New products, impossible to elaborate using the conventional methods or existing equipments, can now be produced. Moreover, product design costs can be reduced [10]. To keep competitors out of reach, the company can legally protect its process through the delivery of a patent. In assembly industries, where each product is the result of multiple operations of manufacture and assembly of elementary components, imitation is challenging because of the complexity of the process [11].

A reorganization of the company's production equipments can be considered as a process innovation. The introduction of a lean production strategy is seen as a process innovation because it has a direct effect on the products production for the market [10].

\section{2) A "skills" perspective}

In this perspective, skills are considered as a core element of the environment.

A project is the field of knowledge exchange between stakeholders. New knowledge results of the interactions between the stakeholders of the project and, with this knowledge, innovation emerges [12]. The competitive advantage is primarily based on knowledge as the main resource. Its transfer is considered as a strategic issue. A skills transfer can take place within the company and between different companies [13]. The knowledge transfer is important for a company, it's necessary to respond to changes, to innovate and to achieve competitive success [14]. Many companies can improve their abilities by assimilating new technologies [15].

All the organizations' knowledge defines their skills and core competencies [13]. The knowledge transfer between individuals or organizations can be defined as a process by which an actor acquires an another actor's knowledge [16]. The transfer can proceed in several ways, such as interaction of personnel, services exchange, or patent disclosures [13].

\section{3) A "stakeholders" perspective}

This perspective focuses on the nature of the members of the ecosystem. There are several variables to characterize a network. The first is actor-based, a network is a system of interrelated actors, including customers, suppliers, competitors and public and private support agencies [17]-[19]. The second type of variables refers to the nature of the relationships: social or business [20], personal [21], or formal business partner or 
informal [22]. Finally, the last definition is structured-based. A network is a set of two or more connected relationships [23], [24].

Collaboration between companies is essential to use additional resources [25]. The network facilitates access to new markets and reduces the time of the innovation process [26]-[28].

Considering the "stakeholders" perspective, one theoretical obstacle emerges concerning the boarder of the studied system. The criteria defining the belonging to a specific supply chain remains fuzzy as the interrelated stakeholder's network may be wide and complex in some cases. Thus the process of listing the stakeholders remains uncertain.

\section{4) A "market" perspective}

This perspective points out the importance of the market in the company's environment.

Segmentation allows determining the company's competitive field and thus, the segment that will be served. Products with different characteristics are not positioned on the same segment. Among segmentation variables are: product variety, customer type, distribution channel and geographical location. The segmentation is derived from the combination of these variables. A competitive strategy is a result from this segmentation. Indeed, the goal of a company is to determine the attractiveness of each defined segments. This strategy essentially depends on the company and interconnections between its value chain activities [2].

One way to collect data from the market consists in the customer integration in innovative projects. Thus the company gets access to a set of knowledge and may benefit from interactions between knowledge [12]. This practice is proposed in the literature by the term "customerization". A dialogue between the customer and a company is created through tools, concepts, methods allowing the transfer of knowledge between the project stakeholders [29].

In the article, we take a company perspective, meaning that we study a central company (in our case ETA) that was leading in developing an innovation (the Swatch watch). We study this company and the actors and factors around it. Observing all stakeholders within the supply chain seems relevant; we would interest us to one company, one that supports innovation, to retain an individual vision of the supply chain. We have deliberately chosen four perspectives because they are complementary to each other. Each perspective focuses the attention on specific aspects. The "production optimization" and "skills" perspective focus on the central company, whereas the "stakeholder" and "market" perspectives focus on various actors outside the central company. The combination of these perspectives creates a complete impression of the relevant internal and external environment of a central company.

\section{RESEARCH APPROACH}

\section{A. Aim of the study}

In this empirical study, we focus on the company ETA to study the Swatch development. This case study is chosen for the following reasons:

- The novelty degree of the product in the market for watches.

- The impact of product on the supply chain.

- The number of publications on the subject enabling a further review.

Moreover in this case it may be stated that project managers have anticipated the misfit between the previous supply chain and their innovative concept. Indeed, they face many constraints: a production cartel, cost pressure among others. At the very first step of the project, new materials are considered and irreparability is chosen, thus the consequence on the environment are obvious.

Note that we choose a theoretical and literature approach to study the changes in the supply chain during the innovation development. Several points are analyzed both internal and external to model the supply chain:

- Process related to the product: design, production, distribution, sales ...

- Resources mobilized (processes, knowledge, knowhow, equipments ...).

- Identification of the main suppliers and customers.

- Flow between actors: material, information, financial...

\section{B. Methodology}

\section{1) Data collection}

The research includes the collection and analysis of data from about ten different documents strictly scientific: books, publications... The data are imperatively extracted from at least two scientific reviews to validate the truthfulness of the information and to get a consistent study. These data are used to develop models that are confronted with research concerning this innovation. There are five analysis phases. 


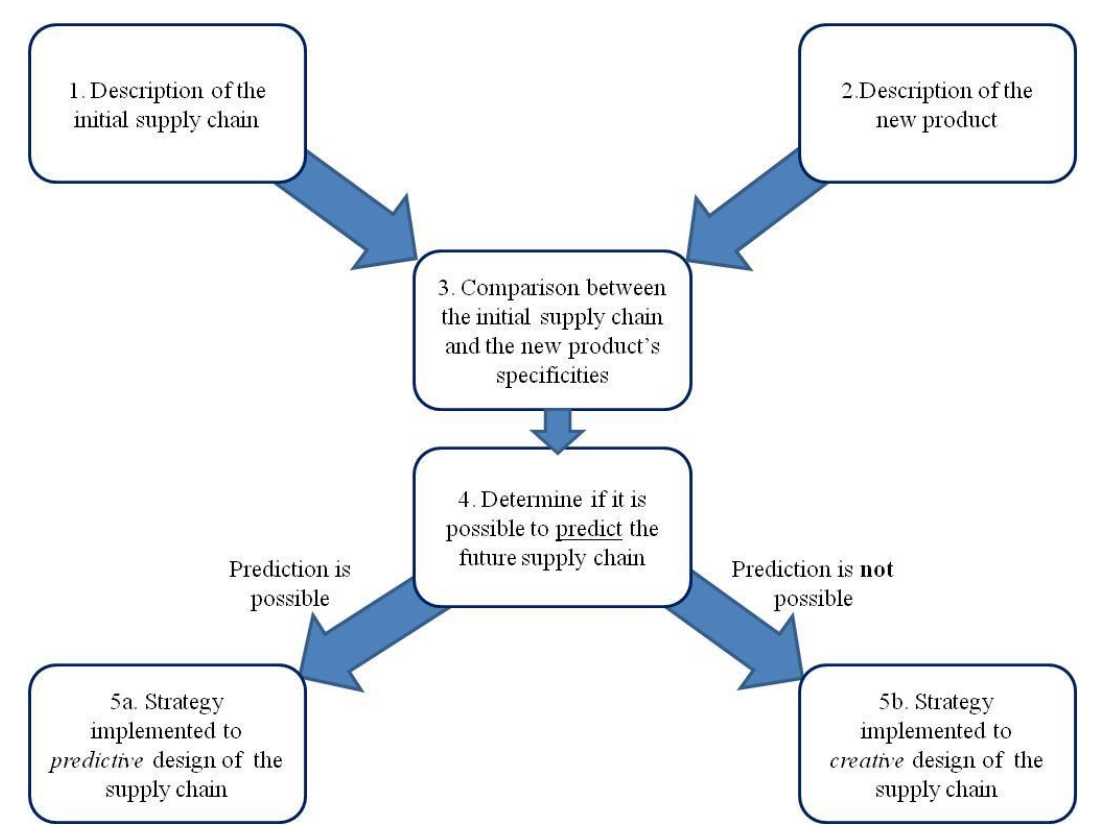

Figure 1: Implemented methodology

a) Phase 1: Description of the initial supply chain and the "traditionnal" product

This step allows identifying all actors involved in the development of the product. There are ranked according to their role and their characteristics in the initial supply chain: suppliers; subcontractors, manufacturers, distributors, customers.

\section{b) Phase 2: Description of the new product}

The description of the new product allows reviewing skills, equipments, technologies required to develop it. This gives information on the company's needs and the supply chain's changes to facilitate the integration of the new product.

c) Phase 3: Comparison between the initial supply chain and the new product's specificities

This step allows visualizing if the new product can be inserted in the existing supply chain. Several elements such as activities, skills, stakeholders and the market are analyzed to assess if there is a fit/misfit between the characteristics of the new product and the existing supply chain. Any emerging misfit indicates that the supply chain has to change.

\section{d) Phase 4: Description of the future supply chain} Following the previous confrontations, two possibilities emerge:

- The future supply chain can be predicted. The company's manager sees the strategic actions to implement to move from a supply chain to another.
- The future supply chain cannot be predicted. The company's manager has to implement an iterative strategic process to move from a supply chain to another.

\section{e) Phase 5: Implemented strategies}

In this last step, the strategies that help to move from a supply chain to another are identified. The impacts from the strategic choices on skills, on relationships between the actors, on the environment, on market are described.

The figure 1 summarizes the previous methodology.

\section{2) Data processing}

During the data processing, several dimensions are designed to have a clear vision of the process followed by the company to incorporate the new supply chain.

Firstly, with the concept of Porter's value chain [2], the company's organization has been analyzed to visualize how the arrival of the new product impacts the internal operation of the company. Then, an external environment analysis of the company is conducted to understand the relationship between the different actors.

\section{3) Data modeling}

Data modeling allows highlighting the supply chain evolutions and associated strategy over time. A systemic approach is used to represent actors and flows. The resulting models are compared and the implemented strategic actions are placed on 
the representation to better understand their impact on the supply chain.

\section{4) Result inventory}

All results are listed in a table where each misfit is retranscribed with the strategy to model the new supply chain.

\section{FINDINGS}

Firstly, the basic facts in the historical evolution of the studied project are transcribed. Secondly, implemented strategies are explained to better understand how the company supports the transition from a supply chain to another.

\section{A. Factual description of the Swatch project development}

\section{1) Supply chain structure before the Swatch project}

The figure 2 represents the initial supply chain.

After the First World War, the Swiss watch industry was reorganizing as a cartel. The cartelization defines industrial activities of the different actors. Trade exchanges take place only between companies belonging to the cartel and according to rules of strict exchange. This system leads to a standardization due to a limited number of suppliers and partitions the market. In this way, market shares were regulated and maintained because new producers can not integrate the market [30]. The production chain from cogs to finished watch was extremely long. There were up to one hundred and fifty different companies involved in the watch design [31].
All members were grouped in a holding company that manages all firms in the same business. The company ETA, as many movement-blanks manufacturers, belonged to the holding Ebauche SA, created in 1926. This holding will then be controlled by a group of Swiss watch manufacturers named ASUAG in 1931[32], [33]. Ebauches SA was the principal company of holding ASUAG, which includes the production of movement-blanks and elements that constitute the watch. For a long time, ASUAG did not sell finished watch [31].

The Swiss watch industry meet two contradictory imperatives:

- to produce in large series to lower production costs

- to diversify production

To meet market requirements, the product has to adapt easily, which seems to be in contrast to the requirement that the product is produced on a large scale. Consequently, the production steps were separated: "movement" manufacturing was relatively standardized whereas watch "casing" was diversified [34].

The movement design was ensured by movement-blanks manufacturers, which carry out the "chassis" of the watch. The company ETA was specialized in movement-blanks in dry brass. Each movement-blanks manufacturer had its field of expertise and was not allowed to use another process. Hence, ETA used only dry brass to manufacture its products, "Ebauches de Fontainemelon" used only wet brass and "Ebauches Electronique" has the monopoly of plastic. The movement-blanks and others parts (cogs, boxes ...) required

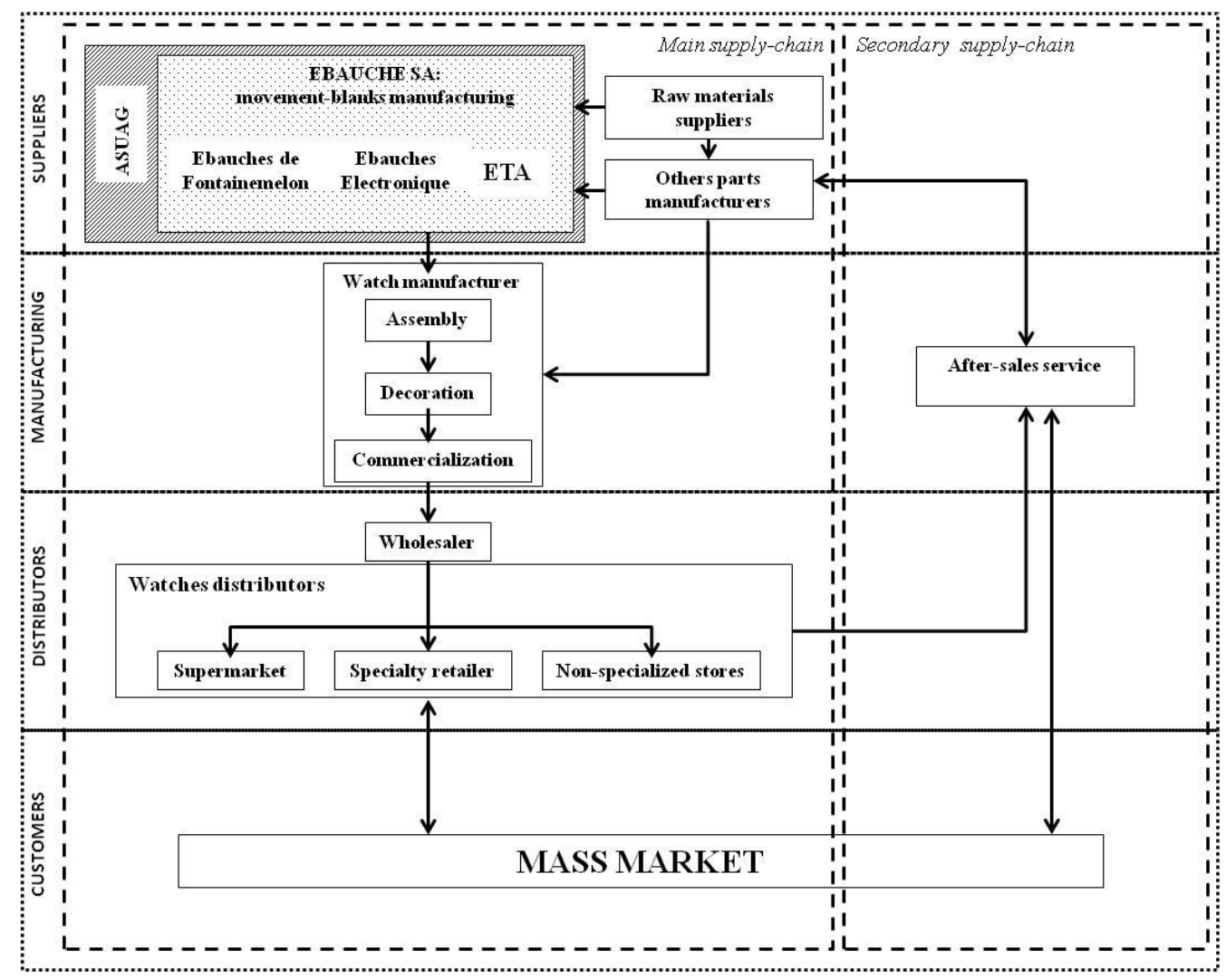

Figure 2: Representation of the initial supply chain 
for assembly were sold to watch manufacturers who put together and commercialize the watch. Finally, trading companies made the links between manufacturers and customers. These are wholesalers specialized in the export or sale to supermarkets or non-specialized stores and also specialty retailers (watchmakers, jewelers) [34]. Manufacturers did not control the retail network. Swiss watchmakers depended on wholesalers and had no direct market access. At that time, the traditional Swiss watches were removable and therefore repairable. Retailers and watch repairers were essential because they help to spread the perfectionist image of the Swiss traditional watch [31].

To conclude, the Swiss watch industry was organized horizontally according to the companies' specialties. Suppliers manufactured all type of components of the watch and then delivered them to the watch manufacturers who assemble and sell watches [35].

At the end of the 1970s, cheap quartz watches from Japan were disrupting the market dominated by the Swiss. The strict rules imposed by the cartel limited the innovation capabilities of companies that were specialized in specific activities. Firms had difficulties to stand out to deal with this crisis [36].

2) Swatch project (1980 - 1985): changes of the company's value chain

In 1980, in the beginning of the project, ETA is only specialized in movement-blanks manufacturing. The company does not assume activities like design-manufacturingdistribution of finished watches, a consequence of the division of labor inherited from the cartelization of the Swiss Watch industry.

Elmar Mock works in ETA since 1976. At the request of the director, he works in secret on plastic injection machine. He begins an ongoing engineering degree in plastics to open up the research field. To expand his experiments, he orders a highprecision injection machine. To justify his request, he makes a sketch of an ultra-simple plastic watch with the help of Jacques Müller,. This drawing shows a technical concept of a future watch with simplified architecture choice: a monocoque housing, a welded glass and a motor attached separately. Ernst Thomke, ETA's manager, recognizes the innovativeness of the proposed concept and encourages the two men to pursue their research.

However, he suggests some guidelines:

- Low manufacturing cost

- Industrial mass production

- Made in Switzerland

- Functioning like a watch (watch hands)
The experiments and training followed by E. Mock help knowledge development: from product compounds to manufacturing processes. This knowledge quickly feeds back into the design of the watch itself. The knowledge is gradually formalized: first, on a technical level and then in terms of marketing and design. Finally, to produce in large-scale series, the industrial processes is designed tested to be reliable [36].

\section{a) Experiments}

The design of the Swatch starts with experimentations and E. Mock's learning on the plastic material and its process. The company focuses on three particular processes:

- Plastic assembling to hold together various plastic components

- Plastic injection to foster the large-scale production

- Plastic colorization

Following his training in plastics processing, E. Mock tries out and offers solutions that facilitate the attachment of the glass on the watch casing. The plastic welding machine manufacturer, Branson, lends him its machines. At the end of 1980, the final decision of the plastics processing process is taken: ultrasonic welding. ETA is gradually adopting new plastic manufacturing knowledge and selects its suppliers [36].

\section{b) Architectural design}

To automate the process, the number of components is strictly limited and the product gets thinner. More than half of the components have disappeared without affecting product quality [36].

\section{c) Marketing}

At the beginning of 1980, the company ETA has no marketing skills. To promote its product, it works on branding and positioning of its product. To diversify the watch industry, the new watch has to look like others but with new properties and a very low price.

In addition, the Swatch is positioned as a fashion accessory, an interchangeable accessory. The process of plastic colorization allows regularly renewing product offerings, which is specific to a fashion accessory [36].

\section{d) Design}

After the six months period fixed by E. Thomke at the beginning of the project, technical and esthetic principles of Swatch are set up. The design of the watch is lyre-shaped. The design of casing, glass, watch hands, bracelet and watch dial are determined a few months later.

A sleek and upscale working definition is then performed. 
The designers work in partnership with experts in plastic injection to ensure that all technical and esthetic requirements are examined. The tactile properties of the watch are the result of this collaboration.

As the Swatch is considered like a fashion accessory, it design requires an artistic touch that is renewed over the collections [36].

\section{e) Design and reliability of industrial process}

The choice of the weld impacts the watch manufacturing process. A welded watch is irreparable requiring a zero defect design. A simplified architecture, by reducing the number of components, facilitates a proper functioning, which improves the reliability of the process and requires an excellent mastery of manufacturing and mass production.

The design of industrial process lasted a few years and the technical and esthetic choices were changed significantly. The physical properties of plastic were confronted with the designers' knowledge: sandblasting the mold which receives the polymer resin results of the work carried out jointly between the designers and experts of plastic injection.

During the three years of testing the industrial process reliability, manual and automatic production operated in parallel: machines pre-assemble small parts of the watch and the final assembly is done manually. The process being new to the watch industry, there are still some defects on the production line. The product distribution in the Swiss market has highlighted the shortcomings of the first series. The Swatch being two years guarantee, Swiss consumers have returned defective products to the network, which allowed modifying and finalizing the process gradually. The final production line has been operational in 1985-1986.

Half of the Swatch's components are pre-assembled before moving on the assembly line, which includes control and assembly operations: control of individual elements, control of pre-assembled components, control during assembly, final control. After manufacturing, each watch is tested for 24 hours at automated controls: tightness, temperature and resistance tests. Components and pre-assemblies are checked [36].

\section{3) Supply chain structure after the Swatch emergence}

The figure 3 represents the new supply chain.

Structural changes within ETA impacted its environment. Indeed, ETA manages completely the production, marketing activities. It keeps the same initial raw materials suppliers. "Zero defect" manufacturing required by the watch removes some stakeholders in the supply chain as the actors in the maintenance chain and after-sales service. Indeed, "zero defect" manufacturing does not require repair and maintenance. Impacts also appeared in the distribution sector.

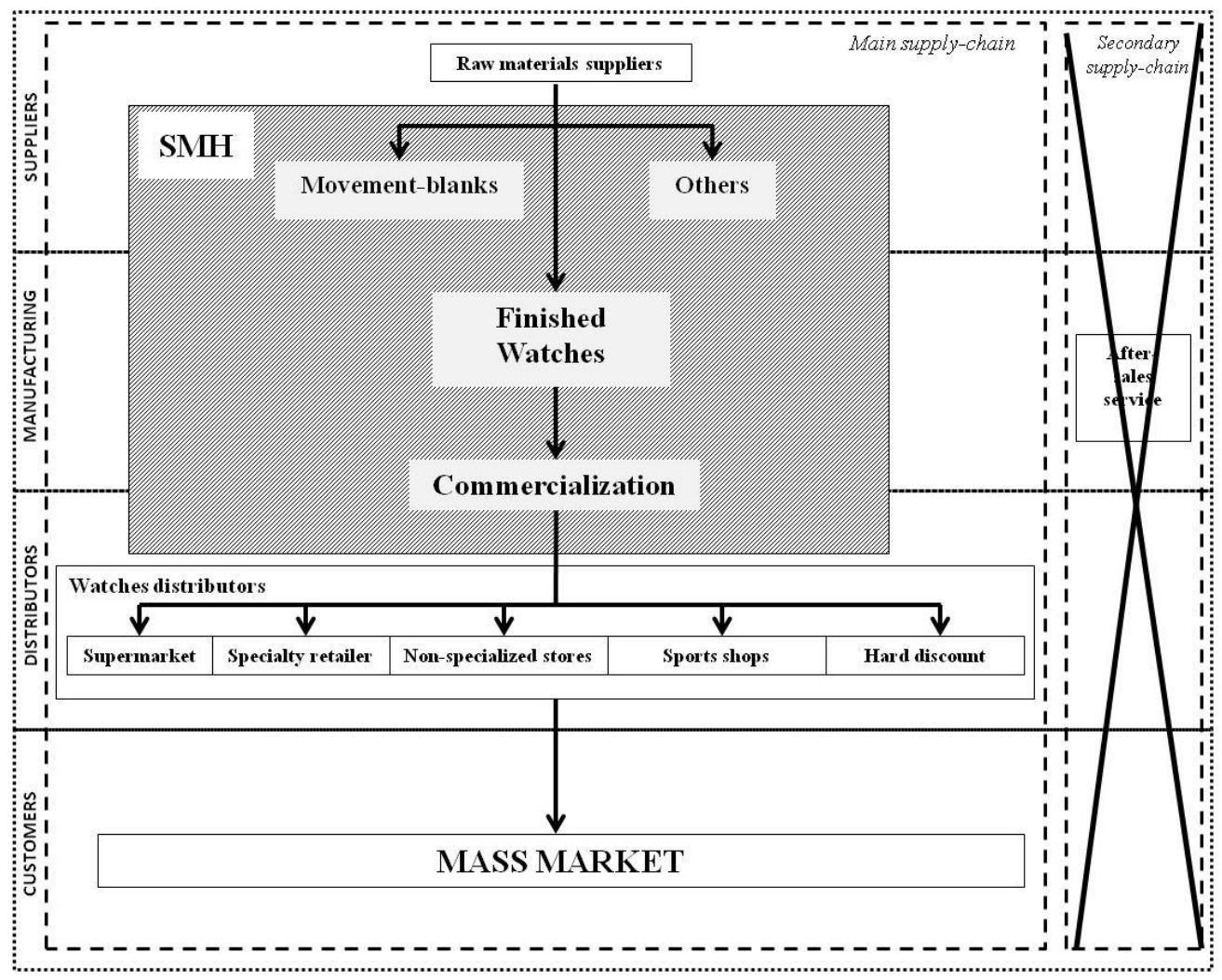

Figure 3: Representation of the new supply chain 
The watch has become irreparable, many distributors like Tissot refused to sell the watch. The company looked to supermarkets, sports shops, and hard discount to sell its products [36].

ASUAG and SSIH merged into a single entity SMH between the years 1983-1986. The creation of this new structure leads to a reorganization. In effect, ASUAG and SSIH were organized both as holding companies with several firms groups. In 1983, all these companies are grouped into three sub-divisions according to their type of activity: finished watches, movements and parts, and, others. [37], [38].

To conclude, the new structure has a vertical orientation, more or less integrated, in which the watch is fully realized by the same company with an internalized production [35].

\section{B. Implemented strategies to adopt innovation}

In order to launch a new activity adapted to the ecosystem, some main strategies have been applied during the new product development phases.

1) Breaking with the cartel structure: Premises of Swatch project

The cartel structure limits companies' initiatives. ETA's director gives a plastic injection machine to E. Mock to no longer depend on other companies like Ebauches Electronics (specialized in movement-blanks in plastic). In parallel of its experiments, E. Mock follows specialized trainings with J. Müller including metals, plastics, and polymers. He participates in an ongoing training in plastic, which allows him working on various plastic manufacturing processes and reflecting about the potential of polymers. These new skills and experiments require more elaborate equipment [36].

Although E. Mock and J. Müller do not belong to the EBAUCHE SA R\&D team, E. Thomke is attracted by their concept represented by a simple drawing. He acquires the necessary equipment and supports them in their research efforts. He sets some principles for the future product before allowing the two engineers conducting their experiments. A simple drawing is enough to convince the manager[36].

Skills and equipments acquisition coupled with the manager's desire helped to trigger the development of innovative product.

2) Swatch project: decision and changes of the company's value chain

At each stage, knowledge interacts with concepts. The acquisition of knowledge and skills from manufacturing and training foster the definition of the new product. a) Strategy and decisions relating to $R \& D$

- Skills acquisition

The numerous learning given to E. Mock and J.Müller help to acquire skills facilitating their experiments. Then the company integrates a genuine R\&D department.

\section{- Partnership}

After his training, E. Mock meets many plastic manufacturing suppliers and especially Branson. This company lends him plastic welding machines [36]. The choice of technology, ultrasonic welding, comes from this partnership with the equipment manufacturer. So, the project attests of an open strategy.

\section{- Product protection}

Two years later, a watch comprising a plastic box with a glass and a method of fixing the glass on the watch box are patented, proving the intellectual property of the managers [36]

\section{b) Decisions and strategy relating to design for manufacturing}

- Cost reduction

J. Müller's experience in cheap watches is essential to decrease the number of components. A limited number of components increase reliability of the product. Reduce by half the number of components simplifies the final assembly and facilitates working in robust and controllable subsets. Then, automated manufacturing is facilitated. Process knowledge is in interaction with product knowledge. In addition, reducing the number of components helps reducing the cost price of the watch [36].

\section{c) Marketing decisions and strategy}

- Skills acquisition / new product positioning Marketing knowledge is acquired through persons outside the company. Not to compete with the traditional Swiss watches, managers have chosen to move towards a low-end product with a lower manufacture cost. In April 1981, E. Thomke works with an independent marketing designer to highlight the consumer's vision. Franz Sprecher first suggests the concept of the watch as a fashion accessory [36], [39], [40].

\section{d) Product Design decisions and strategy}

- Decisions in the field of esthetics

To define the watch's design, E. Thomke mobilizes knowledge outside ETA but also internal designers. G. Coulin is a designer of Metal Product AG, a company absorbed by ETA during the restructuring undertaken by Thomke. He is at the origin of the lyre-shaped. H. Zaugg is an external designer, specializing in 
premises and furniture development. He offers timeless sketches with a minimalist form that reveals the watch face [36].

- Skills acquisition / knowledge transfer

M. Schmid and B. Müller, independent designers, are responsible for the final design of the Swatch. They offer a sleek and upscale definition working. The proposals offered by the designers have an impact on the watch manufacturing process. Skills transfer takes place between designers and experts of plastic injection driven by E. Mock. He integrates designers in the research by training them on the different materials properties, on the constraints of the plastic injection and on the industrial colorization of a plastic watch [36], [40].

\section{e) Decisions and strategy for the production process}

\section{- Zero defect manufacturing}

To ensure zero defect manufacturing, a long period to adjust the process is needed. This is an important step for company that must manage many unrecoverable expensive industrial wastes. Watches not conforming in quality are fully discarded because they are irreparable. With traditional watches, some components are still recoverable which fosters the spare parts logistics and associated stakeholders. The reliability of the process, through tests and customer feedback, impacts the supply chain by removing ancestral links in the Swiss watch industry: maintenance chain and after-sales service [36].

- Lean-production / quality approach

The concept of irreparability is a strong innovation. It stems directly from the choice of manufacturing process, the process influences the product. Moreover, this concept has an impact on the company's quality strategy. Indeed, to facilitate the implementation of product quality control, ETA sets up a new system of measurements. A lean-production with total quality strategy is going to develop. In this way, the company controls its production cycle. This complex process avoids any outsourcing in a country with low labor cost [36].

- $\quad$ Production rationalization within the company

The Swatch production leads to a centralization of movements and parts production within the company ETA. This policy results from the subsidiaries merger of Ebauches SA strategy under the name ETA SA led by Thomke in 1978 [41].The concentration of production enables a rationalization (components reduction) and production automation [37].

The process selection has to meet the guidelines formulated by E. Thomke at the start of the project:
Reducing the number of components to decrease the cost price of the watch and thus its manufacturing cost.

- The automation of the manufacturing process enables large scale production.

- The complexity of the manufacturing process and related controls exclude the outsourcing. The Swatch is a Swiss Made Watch.

- The technical choices don't affect the watch functioning

\section{f) Decisions and strategy in product portfolio}

- Customers feedback

Despite some uncertainties concerning the production process, the combination of manual/automatic productions facilitates the first watches diffusion on the market. This pre-diffusion phase allows the company making reliable its process responding to customers feedbacks. A product/process codesign is continuing while the Swatch is already on the market. The final assembly line only works in 1986 [36].

To sum up a large variety of strategies are applied to ensure the coherence with the economical, marketing and structural variables of the environment.

\section{3) Supply chain structure after the Swatch emergence}

To optimize the development of its product, ETA changes its functioning and its structure. The emergence of the Swatch destabilizes the actors of the initial supply chain. The company manages entirely the production as well as marketing and products distribution. As a consequence, some previous suppliers are no more mobilized, they are removed from the new emerging supply chain. The relation between ETA and its suppliers is also changing, the contracts formalizing their interrelation are more or less based on subcontractors principles instead of colleagues agreement. The downstream market also evolves because at the beginning, the watches retailers do not agree to sell plastic watches. So, the company turns to supermarkets, sports shops, hard discount...

Moreover, the Swatch is irreparable; all actors of involved in maintenance and after-sales service completely disappear.

All these impacts are anticipated by project managers. They foresee the external evolution, and a posteriori, it is possible to determine the coherence between their decision and the provisional effects of their product and technology on the ecosystem.

The Swatch is finally a success story. The SMH's birth, due to the merging between ASUAG and SSIH, allows restructuring production systems and adopting a new market strategy [38]. 
4) Supply chain evolution following the emergence of the Swatch

With this empirical case study, the evolution of an innovative company within its supply chain is observed. Innovation and associated strategies impact the company's role and its supply chain. To summarize the research outcomes, the supply chain is modeled before and after the innovation launching as shown in figure 4. This figure introduces the way we conclude the case study. Each stakeholder is represented by a rectangular box. The previous supply chain is on the left and the new one on the right. Differences may be observed on:

- Stakeholders: Some are unchanged and keep the same role (white box), others are always involved but with a different role (yellow box), some stakeholders disappeared (dashed lines), and some are new (blue box).

- Interrelation: Materials, information, financial transfer between two stakeholders are unchanged (black solid arrow), modified (blue solid arrow) or deleted (dashed arrow).

All implemented strategies that transformed the supply chain are summarized in the following picture. Thanks to a systemic representation, stakeholders involved in the product development are schematized. All mutations within the supply chain are modeled.

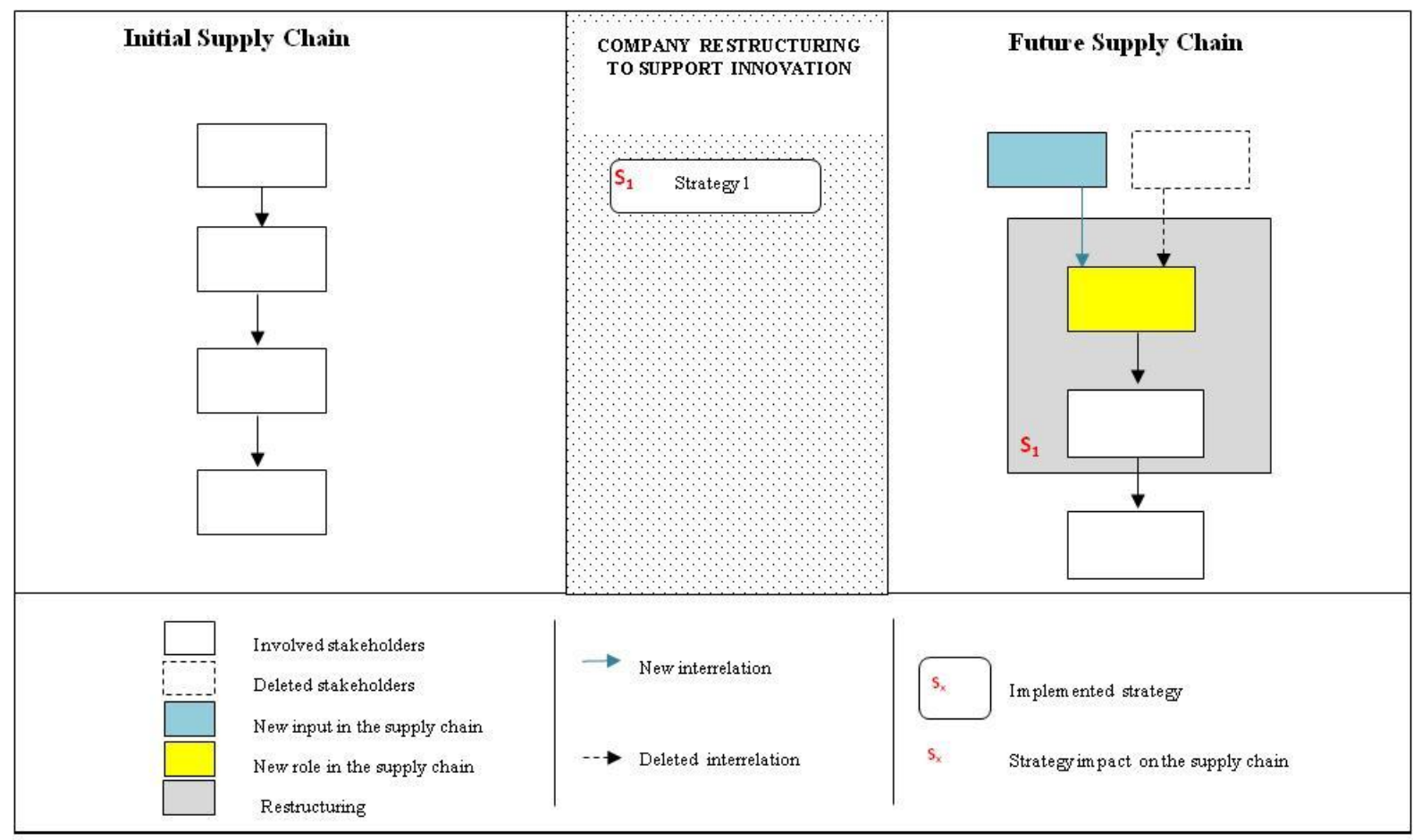

Figure 4: Generic framework to represent impact on the supply chain 


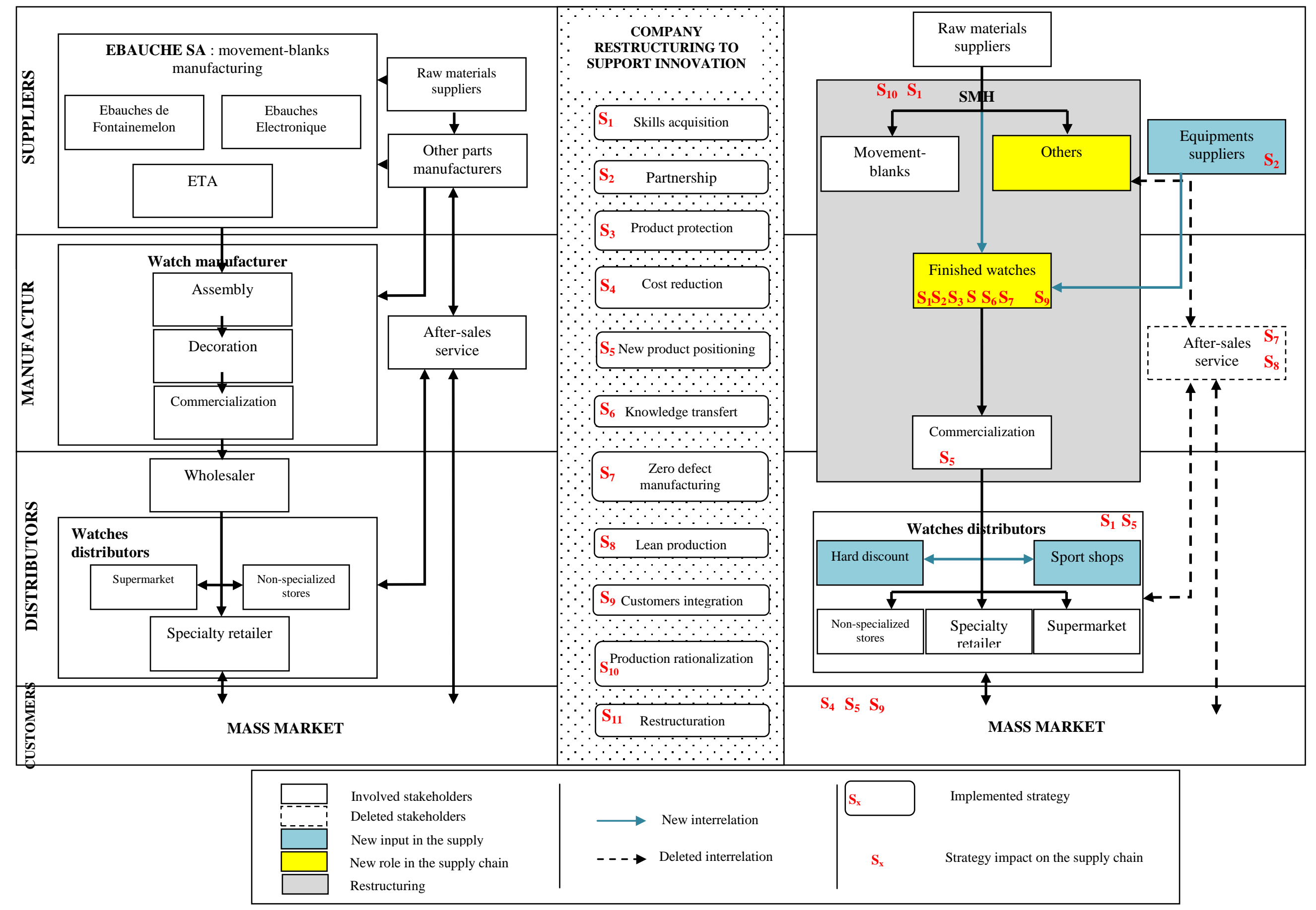

Figure 5: Modeling of all mutations within the supply chain due to ETA's strategic choices 


\section{CONCLUSION}

Table 1: Summary of strategic analysis

\begin{tabular}{|c|c|c|}
\hline Misfit & Implemented strategy & Strategic perspective \\
\hline \multirow{2}{*}{ Missing skills } & Skills acquisition & A "skills" perspective \\
\hline & Knowledge transfer & A "skills" perspective \\
\hline $\begin{array}{l}\text { Limited resources to conduct } \\
\text { experiments }\end{array}$ & Partnership & A "skills" perspective \\
\hline $\begin{array}{c}\text { Innovative technology in the supply } \\
\text { chain }\end{array}$ & Product protection & A "production optimization" perspective \\
\hline \multirow{2}{*}{$\begin{array}{l}\text { Low end product in a highly technical } \\
\text { field }\end{array}$} & Cost reduction & A "production optimization" perspective \\
\hline & New product positioning & A "market" perspective \\
\hline \multirow{2}{*}{ Irreparability concept } & Zero defect manufacturing & A "production optimization" perspective \\
\hline & Lean production & A "production optimization" perspective \\
\hline $\begin{array}{l}\text { Transition from a manual to an } \\
\text { automatic production }\end{array}$ & Customers integration & A "market" perspective \\
\hline \multirow{2}{*}{$\begin{array}{l}\text { Incompatibility between operation in } \\
\text { the cartel functioning and the new } \\
\text { process implementation. }\end{array}$} & Production rationalization & A "production optimization" perspective \\
\hline & Restructuration & A “stakeholders" perspective \\
\hline
\end{tabular}

\section{A. Conclusion of the case study:}

The emergence of an innovation changes the supply chain in which it is inserted. Thus, two sets of descriptive variables may be studied: internal ones (the value chain) and external ones (the supply chain). In our case, managers of the Swatch project face constraints while innovating. Indeed, the cartel organization prevents from developing innovation. This study has highlighted that actually the innovation characteristics do not match the initial supply chain tailored to the old product. Moreover all decisions taken and strategies adopted have been census, highlighting their pertinence regarding the external constraints but also the vision of the new supply chain to be generated. It can be stated that the innovation project is a voluntarist simultaneous construction of a product, an industrial system and an ecosystem.

At the beginning, the company understands that production, marketing, distribution activities will be necessary to guarantee the innovation success. The choice of manufacturing process, ultrasonic welding, is the most significant element (a few months after the project beginning) helping the company visualizing its future supply chain. A series of strategic decisions result from this breakdown in the manufacturing process that will impact the previous supply chain and give opportunity to the emergence of a new one.

The table 1 classifies strategies impacting the supply chain and each strategy is associated with one of the strategic perspectives defined previously in relation with existing therories.

Finally a technology management major concern may be the elaboration of methodologies helping innovators to adapt to or design a new supply chain while designing a new product.
B. Limitation of the case study:

One of the first limit concerns the availability of data and the impossibility of questioning the different stakeholders. Contrary to experiments, this theoretical case study is based only on scientific articles. Thus some information is missing. The difficulty of estimating the time scales limits the study. Some items have been difficult to position, which froze the study. To maintain a dynamic vision and to generate information, it is important to work on in situ cases.

\section{Research Perspectives}

The study of the Swatch is a standalone case that represents the integration of a radical innovation in a conservative market of traditional products. This case allows to question the result of research and to better understand phenomena in a similar case.

The conclusion of this case study shows that there are several strategic perspectives to consider during the supply chain conception. In the following research, we will focus on only two or three perspectives.

In this study, a strong emphasis is placed on changes in the company's value chain whereas the supply chain is our main study. We will particularly focus our future research on "skills" and "stakeholders" perspectives. Indeed, a stakeholders approach is often interpreted through the needs and demand, but in our work, we focus on the skills. 


\section{REFERENCES}

[1] R. Garcia et R. Calantone, «A critical look at technological innovation typology and innovativeness terminology: a literature review », J. Prod. Innov. Manag., vol. 19, nº 2, p. 110-132, 2002.

[2] M. Porter, L'avantage concurrentiel, Trad. InterEditions. Paris, 1986.

[3] M. L. Christopher, Logistics and Supply Chain Management, Pitman Publishing. Londres, 1992.

[4] G. Assogba et S. Klebaner, «Vers un cadre d'analyse institutionnaliste de la politique de filière: Quelle cohérence pour la politique de filière française?», Cahiers du GREThA, $n^{\circ} 2015$ - 26, 2015.

[5] H. Stadtler et C. Kilger, Supply Chain Management and Advanced Planning: concepts, models, software and case studies, Editions Springer Verlag. 2000.

[6] J. De Rosnay, Le macroscope. Vers une vision globale, Edition du Seuil. 1975.

[7] J.-L. Le Moigne, La modélisation des systèmes complexes, Dunod. Paris, 1990.

[8] J.-L. Le Moigne, La théorie du système général, théorie de la modélisation, 3ème édition mise à jour, PUF. Paris, 1990.

[9] J. Schumpeter, The Theory of Economic Development, Harvard University Press. Cambridge, Massachusetts, 1934.

[10] OCDE, Manuel d'Oslo: principes directeurs pour le recueil et l'interprétation des données sur l'innovation. OECD Publishing, 2005.

[11] D. Guellec, Economie de l'innovation. 2009.

[12] G. Gurgul, M. Rumyantseva, et E. Enkel, «Customer Integration - Establish a constant bilateral knowledge flow ». University of St Gallen, 2002.

[13] V. Albino, A. C. Garavelli, et G. Schiuma, « Knowledge transfer and inter-firm relationships in industrial districts: the role of the leader firm », Technovation, vol. 19, no 1, p. 53-63, nov. 1998.

[14] W. M. Cohen et D. A. Levinthal, « Absorptive capacity: a new perspective on learning and innovation », Adm. Sci. Q., p. 128-152, 1990.

[15] M. Gilbert et M. Cordey-Hayes, «Understanding the process of knowledge transfer to achieve successful technological innovation », Technovation, vol. 16, $\mathrm{n}^{\circ} 6$, p. 301-312, 1996.

[16] R. S. Cutler, « A comparison of Japanese and U.S. hightechnology transfer practices », IEEE Trans. Eng. Manag., vol. 36, nº 1, p. 17-24, 1989.

[17] N. E. Coviello et H. Munro, «Growing the entrepreneurial firm: Networking for international market development », European Journal of Marketing, p. 49-61, 1995.

[18] N. Evers et J. Knight, «Role of international trade shows in small firm internationalization: a network perspective », Int. Mark. Rev., vol. 25, n ${ }^{\circ}$ 5, p. 544-562, 2008 .
[19] M. Zain et S. I. Ng, «The impact of network relationship on SMEs' internationalization process », Thunderbird Int. Bus. Rev., vol. 48, $\mathrm{n}^{\mathrm{o}} 2$, p. 183-205, 2006.

[20] N. Evers et C. O’Gorman, «Improvised internationalization in new ventures: The role of prior knowledge and networks », Entrep. Reg. Dev., vol. 23, $n^{\circ}$ 7-8, p. 549-574, 2011.

[21] S. Harris et C. Wheeler, «Entrepreneurs' relationships for internationalization: Functions, origins and strategies », Int. Bus. Rev., vol. 14, n 2, p. 187-207, 2005.

[22] T. Kontinen et A. Ojala, «Network ties in the international opportunity recognition of family SMEs », Int. Bus. Rev., vol. 20, no 4, p. 440-453, 2011.

[23] S. Chetty et D. Blankenburg Holm, «Internationalisation of small to medium-sized manufacturing firms: A network approach », Int. Bus. Rev., vol. 9, $\mathrm{n}^{\circ}$ 1, p. 77-93, 2000.

[24] N. E. Coviello et H. Munro, « Network relationships and the internationalization process of small software firms », Int. Bus. Rev., vol. 6, nº 4, p. 361-386, 1997.

[25] B. Wernerfelt, «A resource-based view of the firm », Strategic Management Journal 5 (2), p. 171-180, 1984.

[26] A. Arora et A. Gambardella, « The changing technology of technological change: general and abstract knowledge and the division of innovative labour », Research Policy 23 (5), p. 523 -532, 1994.

[27] J. Hagedoorn et J. Schakenraad, «A comparison of private and subsidized inter-firm linkages in the European IT industry », Journal of Common Market Studies 31, p. 373-390, 1993.

[28] R. . Rycroft et D. E. Kash, « Self-organizing innovation networks: implications for globalization », Technovation, p. 187-197, 2004.

[29] P. Krawtchenko, «Contribution à l'étude de l'intégration du client dans la conduite de projets innovants », Université de Lorraine, Nancy, 2004.

[30] H. Pasquier, « Acteurs, stratégies et lieux de "Recherche et Développement" dans l'industrie horlogère suisse, 1900-1970 », Entrep. Hist., vol. 3, n ${ }^{\circ}$ 52, p. 76-84, 2008.

[31] C. Aguillaume, «Les horlogers suisses face à la mondialisation (1968-1983)», Cah. Récits, $\mathrm{n}^{\mathrm{0}}$ 3, p. 57-76, 2004.

[32] A. Glasmeier, «Technological discontinuities and flexible production networks: The case of Switzerland and the world watch industry », Elsevier Sci. Publ., 1991.

[33] O. Crevoisier, «Les grandes entreprises et le changement structurel au niveau régional: le cas de la Société suisse de micro-électronique et d'horlogerie S.A. », Rev. Econ. Régionale Urbaine, vol. 2, p. 301-316, 1995. 
[34] D. Bony et F. Eymard-Duvernay, «Cohérence de la branche et diversité des entreprises : étude d'un cas », Econ. Stat., vol. 144, n 1, p. 13-23, Mai 1982.

[35] C. Rognié et P. Vivien, «Le marché de l'horlogerie : Réflexions et orientations », 2012.

[36] G. Garel et E. Mock, La fabrique de l'innovation, Dunod. Paris, 2012.

[37] P.-Y. Donzé, « Le retour de l'industrie horlogère suisse sur le marché mondial: une business history du Swatch Group (1983-2010)». Université de Neufchâtel Working Paper 4, 2011.

[38] P.-Y. Donzé, A business history of the Swatch Group: The Rebirth of Swiss Watchmaking and the Globalization of the Luxury Industry. Palgrave Macmillan UK, 2014.

[39] C. Lury, Brands: The logos of the global economy, International Library of Sociology. 2004.

[40] R. Carrera, Swatchissimo, 1st Edition. L'amateur, 1992.

[41] G. Vogt, «ETA ». DHS. 